\title{
Sexual dimorphism and identification of single nucleotide polymorphism of growth hormone gene in muscovy duck
}

\author{
Ismoyowati $^{1}$, E. Tugiyanti ${ }^{1}$, M. Mufti ${ }^{1}$ and D. Purwantini ${ }^{2}$ \\ ${ }^{1}$ Poultry Production Laboratory, Faculty of Animal Science, \\ Jenderal Soedirman University, Jl. Dr. Soeparno 60, Purwokerto 53112 - Indonesia \\ ${ }^{2}$ Animal Breeding Laboratory, Faculty of Animal Science, \\ Jenderal Soedirman University, Jl. Dr. Soeparno 60, Purwokerto 53112 - Indonesia \\ Corresponding E-mail:moy.moyowati@gmail.com
}

Received March 06, 2017; Accepted May 09, 2017

\begin{abstract}
ABSTRAK
Penelitian ini bertujuan untuk mengetahui perbedaan pertumbuhan dan mengidentifikasi polimorfisme gen growth hormon pada itik manila. Materi penelitian menggunakan itik manila umur sehari sebanyak 200 ekor yang terdiri dari itik jantan dan betina warna bulu putih serta itik jantan dan betina warna bulu kombinasi hitam putih. Pengukuran bobot badan itik dilakukan setiap minggu, data yang diperoleh dianalisis dengan uji t. Desain primer berdasarkan database dari genebank gen GH Cairina moschata, dengan parsial cds (AB158762). Urutan basa primer gen growth hormone adalah forward primer: 5'-CTGGGGTTGTTTAGCTTGGA-3' dan reverse primer:5'TAAACCTTCCCTGGCACAAC-3'. Hasil sekuensing produk PCR dianalisis menggunakan bioedit version 7.7 untuk mengetahui adanya polimorfime gen GH. Hasil penelitian menunjukkan pada umur yang sama itik manila jantan menghasilkan pertambahan bobot badan dan pertumbuhan relatif lebih besar dibandingkan dengan itik betina. Pertambahan bobot badan itik manila paling tinggi pada umur 3 minggu, kecepatan pertumbuhan mulai menurun pada umur 4 minggu. Hasil sekuensing produk PCR diperoleh adanya polimorfisme nukleotida. Posisi 136 nt terdapat genotip AA pada itik manila betina hitam, CC pada itik manila jantan hitam dan putih, serta itik manila betina putih. Penelitian disimpulkan pertambahan bobot badan itik manila jantan umur 3 minggu lebih tinggi dibandingkan dengan itik betina dan terdapat polimorfisme gen GH pada itik manila.
\end{abstract}

Kata kunci : itik manila, polimorfisme growth hormone, sex dimorfisme

\begin{abstract}
This research was aimed to investigate the different growth and to identify growth hormone gene polymorphism in Muscovy ducks. Two hundred Muscovy day-old ducks consisting of white-plumed male and female duck, black and white-plumed male and female ducks. Body weight was recorded weekly and the obtained data were subject to T test. Primer design used the Custal X Program based on a database from the GeneBank Cairina moschata GH gene, partial cds (AB158762). Primer base sequence of GH gene was forward/Sequence: 5'-CTGGGGTTGTTTAGCTTGGA-3' and reverse/Sequence: 5'-TAAACCTTCCCTGGCACAAC-3'. The DNA sequences were aligned by using the BioEdit version 7.7 for identification of the single nucleotide polymorphism. The result showed that male Muscovy duck produced higher an average body weight gain and more relative growth than those of females. The highest body weight gain was at three weeks old, and then it started to decrease at four weeks old. The sequencing PCR product obtained nucleotide polymorphism. AA genotype was observed at $136 \mathrm{t}$ of black female Muscovy duck, CC in black and white male Muscovy duck, and white female
\end{abstract}


Muscovy duck. Conclusively, a body weight gain of 3-week-old male Muscovy ducks was higher than that of females and GH gene polymorphism was observed in Muscovy ducks.

Keywords : growth hormone polymorphism, Muscovy duck, sexual dimorphism

\section{INTRODUCTION}

Genetic improvement of the sire and dam lines has given poultry geneticists the opportunity to take advantage of various traits in different parental lines. When selecting females for growth traits, decreases in reproductive performances occur as a result of the negative genetic correlation between them (Narinc et al., 2014). Therefore, selection programs in commercial broiler companies are based on multiple selection methods for reproduction and growth traits (Szwaczkowski, 2003). The growth rate of ducks and geese is fast at the early stages of life, and then it slows down (Knízetová et al., 1991). Broiler chickens grow more slowly than ducks and geese in the first few weeks of their life and faster in the subsequent week. This is due to differences in the growth rates of different tissues in the above species (Murawska, 2012).

Sexes play different roles in reproduction and the adaptive significance of the often remarkably distinct morphologies of adult males and females and this is documented frequently. Because of their different roles in reproduction, males and females are often under-a selection that favors their divergent morphological appearance (Badyaev, 2002). Different body weights between male and female fowl is called sexual dimorphism. Waterfowl such as male Muscovy duck at slaughter age (12 weeks) is $40 \%$ heavier than the female and even $65 \%$ heavier in adulthood.

In contrast, male and female chicken have lower body weight differences (15-20), therefore the body composition differs (Mignon-Grasteau et al., 1998). Sexual dimorphism is considered to determine slaughter age in Muscovy duck breeding programs. Higher growth rates in male Muscovy causes slaughter at a younger age. Higher difference in body weight between male and female Muscovy is the obstacle for natural mating. Female Muscovy ducks are often injured in the leg and chest upon supporting the much heavier male. In Muscovy, significant difference in male and female body weight is observed from 3 weeks old and constantly increases. Several endocrine factors interact to control fowl growth and development. Thyroid hormone (triiodothyronine and thyroxin), growth hormone (GH) and growth factors such as insulin (IGF-I and -II) are the main regulator (Ba'eza et al., 2001).

One of quantitative traits, growth, refers to a chromosome part or genetic maps that is statistically correlated with a variation called Quantitative Trait Locus (QTL). QTL is determined by genotype variation presented by some markers in genetic map and the measured phenotype variation. Identification and use of quantitative traits in QTL level can improve genetic characteristics faster, particularly for those unimprovable through conventional selection (Hansen et al., 2005).

Molecular identification can serve as genetic markers to reveal interspecies difference, phylogeographic and intra-family genetic relations for polymorphism study. Identifying polymorphism based on nucleotide sequence is through Single Nucleotide Polymorphism (SNP) using PCR products. Several studies identified molecular genetic variation based on SNP using growth hormone $(\mathrm{GH})$, but to date, no study on identifying gene polymorphism in Muscovy duck in Indonesia has been conducted. This research was aimed to investigate the different growth and growth hormone gene polymorphism between male and female Muscovy ducks.

\section{MATERIALS AND METHODS}

\section{Birds and Characteristics Description}

The experimental protocols were approved by the Animal Ethics Committee of Jenderal Soedirman University. Two hundreds day-old Muscovy ducks (DOD) consisting of males and females, 100 birds each, which were tagged and grouped based on sex and plumage color, and kept in $1.5 \times 2 \mathrm{~m}$ brooder cages up to 14 days old. Broiler feed was rationed from 1-14 days containing $12 \%$ water, $3000 \mathrm{kcal} / \mathrm{kg}$ metabolic energy, $19 \%$ crude protein, $5 \%$ crude fat, $6.5 \%$ ash, $1.1 \%$ calcium and $0.95 \%$ phosphor. From 15 days old, each 10 ducks were kept in $2 \times 2$ m colony cages and fed with $35 \%$ cornmeal, $45 \%$ rice bran and $20 \%$ duck concentrate containing $15 \%$ crude 
protein, $2800 \mathrm{kcal} / \mathrm{kg}$ metabolic energy, 2.035\% calcium and $1.604 \%$ phosphor.

DOD body weight was measured and weight gain was recorded weekly. The average growth rate over a period of time is calculated by dividing the increase in weight over a particular time period by the length of that period $\left(\mathrm{w}_{2}-\mathrm{w}_{1} / \mathrm{t}_{2}-\mathrm{t}_{1}\right)$. The relative growth rate is calculated as the increase in weight over a period of time divided by the initial weight [(w2 - w1)/w2] x $100 \%$ (Warris, 2000). The obtained data were subject to a t-test.

\section{Blood Sample and DNA Isolation}

Blood sample, $3 \mathrm{ml}$ was taken from vena axillaries, put in tube filled with anticoagulant (ETDA) and stored in the fridge. Deoxyribo Nucleic Acid (DNA) total genome was extracted from blood samples and isolated with DNA Isolation Kit (Geneaid). DNA isolation results were examined using $1 \%$ agarose gel electrophoresis.

\section{Primer Design and Amplifying DNA Fragment with PCR}

Primer design used Clustal X program with Cairina moschata $\mathrm{GH}$ gene for growth hormone and partial coding DNA sequence or cds (AB158762) database from GeneBank. Primer base sequence of $\mathrm{GH}$ gene was Forward/ Sequence: 5'-CTGGGGTTGTTTAGCTTGGA-3' and Reverse/ Sequence: 5'TAAACCTTCCCTGGCACAAC-3'. Polymerase Chain Reaction (PCR) comprised several steps, namely DNA pre-denaturation at $94^{\circ} \mathrm{C}$ for $5 \mathrm{~min}$, DNA denaturation at $94^{\circ} \mathrm{C}$ for $30 \mathrm{~s}$, annealing at $58.1^{\circ} \mathrm{C}$ for $45 \mathrm{~s}$ and elongation at $72^{\circ} \mathrm{C}$ for $1 \mathrm{~min}$. Final extension was performed at $72^{\circ} \mathrm{C}$ for $5 \mathrm{~min}$. PCR conducted 35 cycles. PCR products were subject to electrophoresis test with $1.5 \%$ agarose gel.

\section{DNA Sequencing}

PCR product was carried out by Genetika Science-Indonesia-Ltd. Sequencing and the result was nucleotide sequence and electropherogram graphic with colored peaks to differ nitrogen bases (nucleotide) in that green was for Nucleotide A (Adenine), black for nucleotide G (Guanine), blue for nucleotide C (Cytosine) and red for nucleotide $\mathrm{T}$ (Thymine). The DNA sequences were aligned by using BioEdit version 7.7 for identification of the single nucleotide polymorphism.

\section{RESULTS AND DISCUSSION}

\section{Different Growth of Male and Female}

Muscovy ducks belong to waterfowl with sexual dimorphism, or different body weight between the males and females. Sex, both male and female, is important for reproduction and morphological adaptation. Morphological differences during growth and development are prevalent in fowl to adulthood. Fast evolution in setting and sex-specific modification result in sexual dimorphism in body measure but maintained sexual organ development.

The result showed that at the same age, male Muscovy had a higher average body weight gain and more relative growth than the females (Figures 1, 2 and 3). The optimum body weight gain was at three weeks old (Figure 2), and then the growth rate decreased at 4 four weeks old (Figure 3). It was in line with Mignon-Grasteau et al. (1998); Ba'eza et al. (2001) that male and female Muscovy had relatively similar early hatching weight and growth rate, but from 4 weeks old, males Muscovy were higher than the females (Figure 1). Dimorphism appeared to be highly and positively correlated with body weight of males, and positively, but moderately correlated with body weight of females in both species.

In ducks, this trend was more pronounced for weight gain, the trait showing the greatest sexual dimorphism. For ratios, estimates of genetic correlation with body weight at the same age were positive in males and negative in females, except for weight gain, which was slightly negatively correlated with the ratio for weight gain (Mignon-Grasteau et al. (1998). Ba'eza et al. (1999) reported that mean body weights for males and females Muscovy were 44 $\pm 4 \mathrm{~g}$ and $45 \pm 3 \mathrm{~g}$ at $1 \mathrm{~d}$ of age, respectively, and reached $4573 \pm 408 \mathrm{~g}$ and $2879 \pm 210 \mathrm{~g}$ at 15 weeks of age, respectively.

The effect of sexual dimorphism was significant for body weight from 4 weeks of age onwards. The sexual dimorphism of Muscovy ducks and its marked effect on muscular and body growth. The study also demonstrated the difference in growth rate between sexes, with females displaying earlier body and muscular development.

This study was also in line with several previous studies. The drakes Muscovy were 


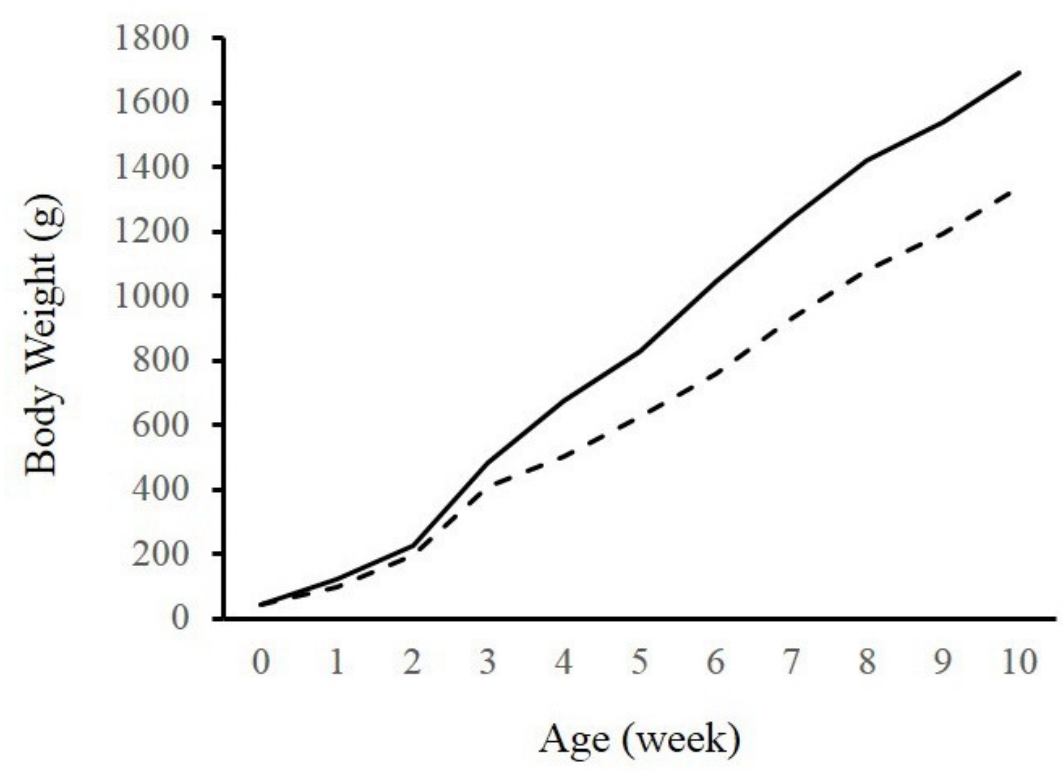

Figure 1. Body Weight of Muscovy Duck. ( - ): Male; ( - ) : Female

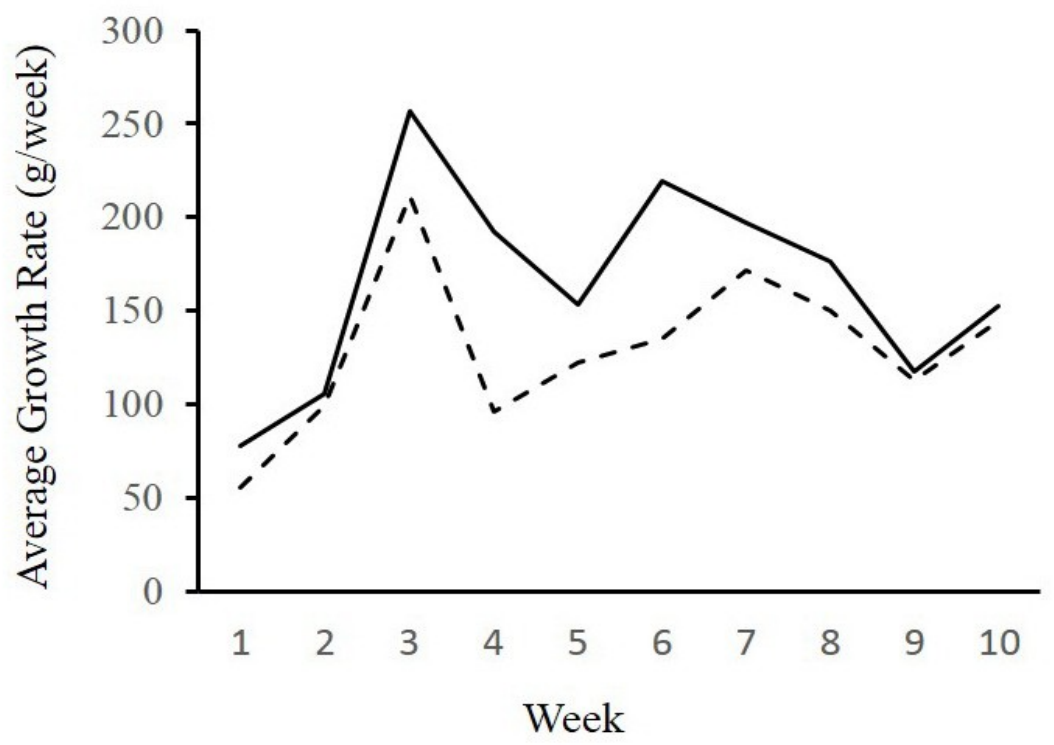

Figure 2. Body Weight Gain of Muscovy Duck. (-): Male; ( - - ): Female

superior $(\mathrm{P}<0.01)$ to the ducks for body weight and all the body characteristics studied. The average body weight for males and females were $2.71 \mathrm{~kg}$ and $1.46 \mathrm{~kg}$, respectively (Raji et al., 2009). From week 1 to 8 , the body weight of ducks increases over 16-fold, the total weight of edible parts in ducks increases approximately 23fold, while the total weight of nonedible parts increases approximately 12-fold (Murawska, 2012).

The proportions among tissue components change as well over that period. In 1-week-old ducks, edible components consisted of approximately $40 \%$ muscle tissue, $37 \%$ skin and fat, and $24 \%$ giblets. At 8 wk of age, meat accounts for $50 \%$ total edible weight-skin and fat 


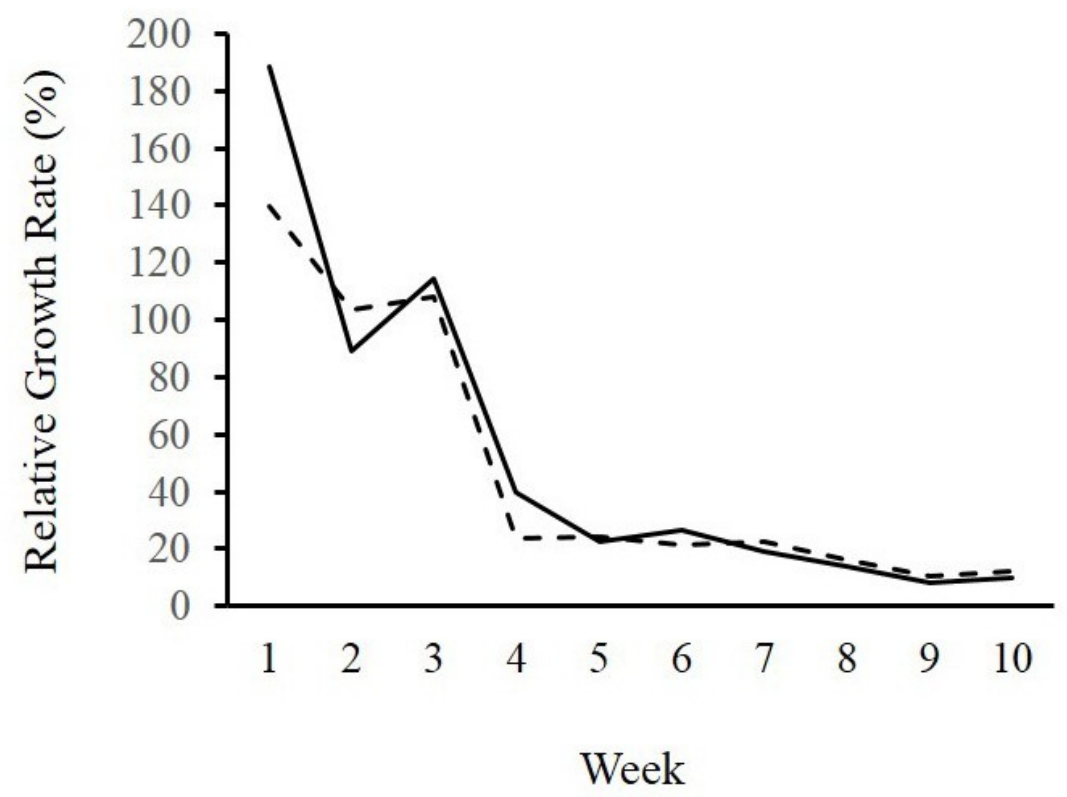

Figure 1. Relative Growth of Muscovy Duck. ( - ): Male; (- ): Female

for $41 \%$, and giblets for only $9 \%$. Greater changes are observed in chickens over the same period: the weight of edible and non edible components increases 37-fold and 18-fold, respectively (Murawska et al., 2011).

Higher body weight gain in male Muscovy is due to dimorphism in Muscovy duck, which that is the different growth rate because of different growth hormone concentration in male and female duck. Growth hormone (GH) level in blood plasma of female Muscovy was highly varied (14$24 \mathrm{ng} \times \mathrm{mL}(-1))$ during the first 4 weeks, while the highest GH plasma in male Muscovy was during the first 7 weeks.

GH level, then decreased 3-4 ng x mL (-1)) and remained low up to 15 weeks old. Different GH concentration occurred in 6-7 weeks old, higher in male than female. IGF-I level in blood plasma increased sharply at 2 and 3 weeks old, remained high up to 6-7 weeks old in female and 13 weeks old in male, then started to decrease. Different concentration (insulin-like growth factor I) IGF-I was very significant between male and female duck, namely higher in male at 7,12 and 14 weeks old.

Different GH and IGH-I level in male and female ducks caused a higher growth in males than females, or commonly known as sexual dimorphism (Ba'eza et al., 2001). Sexual size dimorphism is found in the weight of the tibia bone and tarsometatarsol in male ostriches were heavier and longer than those in females (Charuta et al., 2013).

\section{Growth Hormone (GH) Gene Polymorphism}

The expressed product of the GH gene is the protein growth hormone $(\mathrm{GH})$, also called somatotropin, produced in specific cells (somatotrophs) of the pituitary gland Growth hormone has many physiological functions, such as promoting muscle growth, bone growth and development, regulation of fat content and metabolism (Zhang et al., 2007; Ge et al., 2012; Mazurowski et al., 2015).

Studies in animals indicate that $\mathrm{GH}$ is involved in the processes of sexual differentiation, pubertal maturation and participates in gonadal steroidogenesis, gametogenesis and ovulation (Hull and Harvey, 2001). In birds, GH has an important function in growth, but is also involved in a variety of secondary functions such as egg production, aging and reproduction (Kansaku et al., 2003).

GH gene polymorphism observations carried out on Muscovy ducks, differentiated by sex and plumage color (white, a combination of white and black with white dominant color, a combination of black and white with black dominant color). Plumage color and development is particularly important in ducks because carcass quality 
deteriorates during the feathering process, which affects the processing suitability of raw material.

Base variation or polymorphism resulted from replication process is called Single Nucleotide Polymorphism (SNP) and differ one individual from another (Sudoyo, 2004). Nucleotide polymorphism at 136 nucleotide (nt) was derived from sequencing PCR products. AA genotype was observed at $136 \mathrm{nt}$ in black female Muscovy, CC in black and white male Muscovy and white Muscovy. GG genotype at 137 nt was observed in female Muscovy, but not in other ducks, assumedly due to-inversion.

Polymorphism was apparent in that position. Polymorphism was also investigated from electropherogram result (Figure 4 and Figure 5), where nucleotide difference was found between black female Muscovy, black and white male Muscovy and white female Muscovy at $136 \mathrm{nt}$.

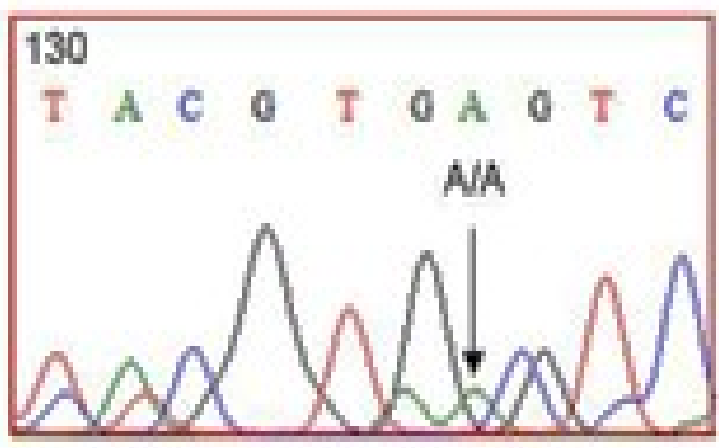

Figure 4. GH Gene Electropherogram in Female Muscovy Duck (Combination of Black and White with Black Dominant Plumage Color)
The difference was AA genotype in black Muscovy and $\mathrm{CC}$ in black and white male and white female. In the Muscovy duck population, the frequency of the A allele (0.2) was smaller than the $\mathrm{C}$ allele $(0.8)$. The frequency of the allele of $\mathrm{GH}$ gene in each population based on feather color was shown in Figure 6. A female Muscovy duck population with white-black feather color shown the highest variation compared to male and female population of white and white-black combination. The heterozygosity value of female Muscovy duck population with white-black feather color was the highest than other populations (Figure 7.). The GH gene is highly polymorphic in a variety of livestock animals. Many polymorphisms have been identified in the GH gene of poultry (Shenghai et al., 2007; Ghelghachi et al., 2013; Zhang et al., 2014). In ducks, the effect of $\mathrm{GH}$ gene polymorphism on

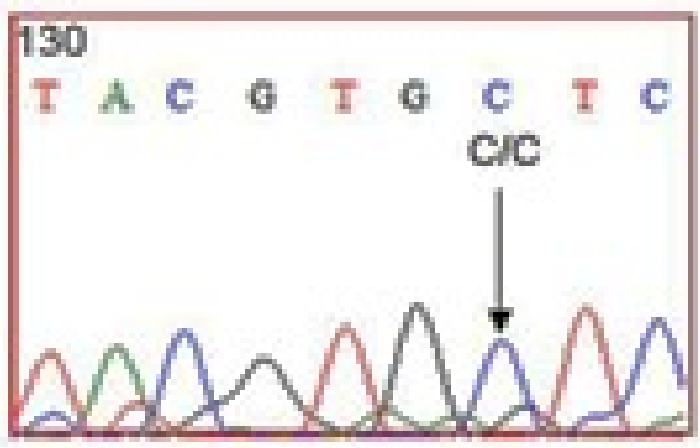

Figure 5. GH Gene Electropherogram in Male and Female Muscovy duck (White, a Combination of White and Black with White Dominant Plumage Color)

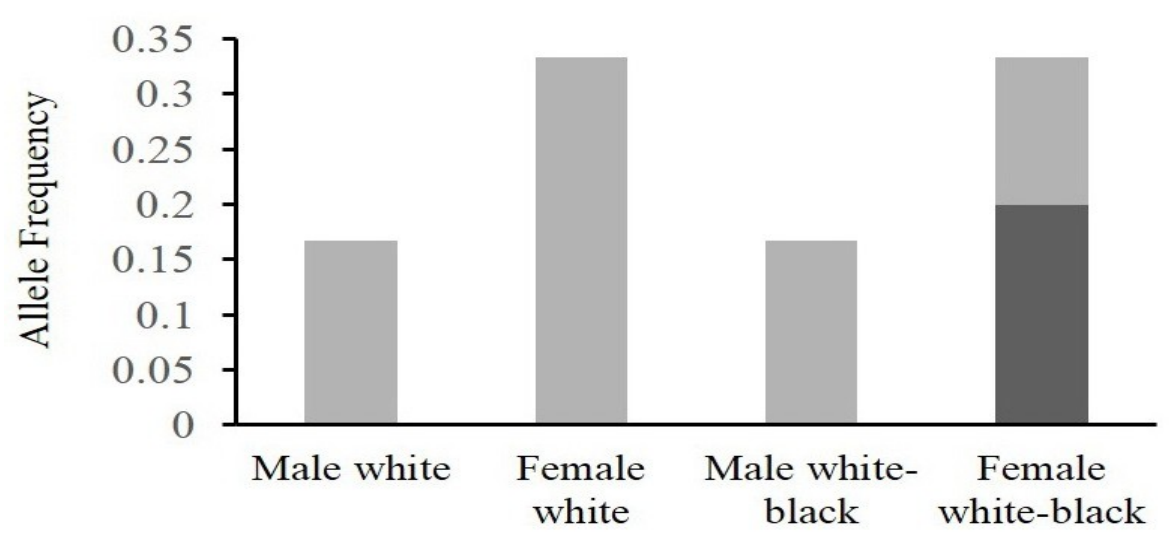

Figure 6. Allele Frequency of Muscovy Duck Populations. $\square$ :C; : A. 


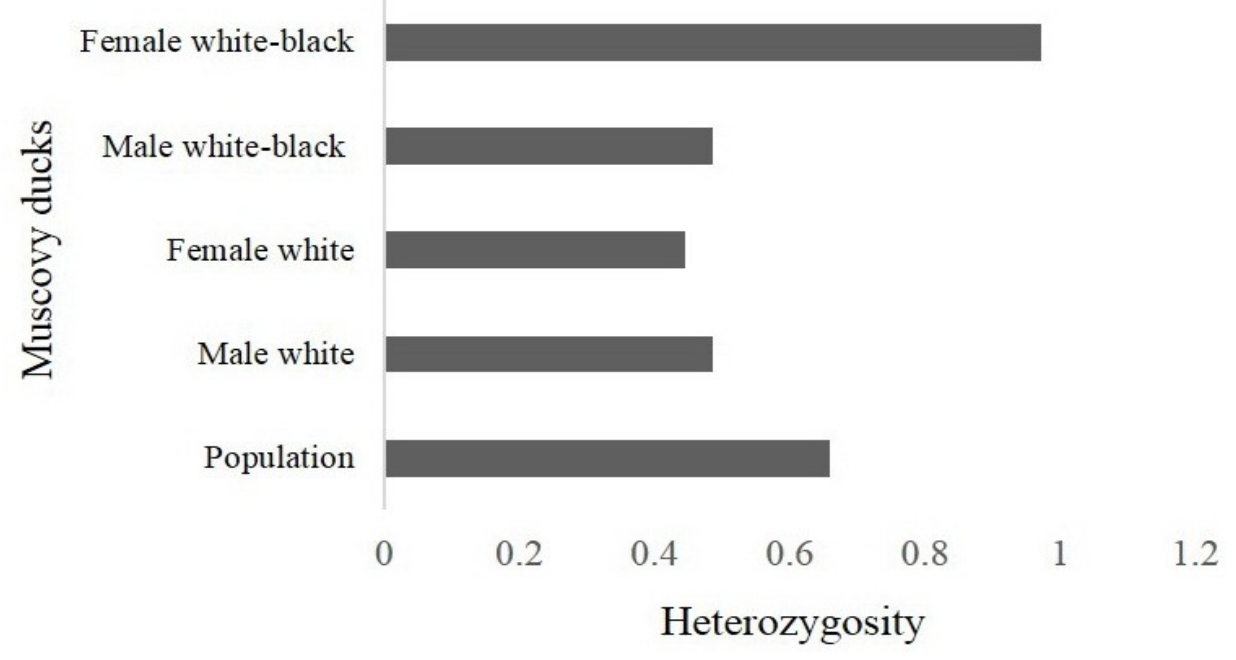

Figure 7. Heterozygosity Value of Muscovy Duck Populations

important economic traits has been noted (Wu et al., 2012; Wu et al., 2014).

Different genotype was due to an error in duplicating genetic information (replicating) that caused mutation in DNA molecules. The mutation was accumulated from generation to generation; hence, the farther genetic relation between two individuals, the bigger mutation difference carried by the DNA (Sudoyo, 2004). Hai et al., 2007 reported three SNPs, $230(\mathrm{C} \rightarrow \mathrm{G}), 244(\mathrm{C} \rightarrow \mathrm{A})$ at 5'-UTR and $3701(\mathrm{C} \rightarrow \mathrm{T})$ in 4 exons of growth hormone gene in various native Chinese ducks such as Peking duck, Xihu Mallards, Cherry Valley meat ducks, Jinding duck, Shan Partridge duck, Shaoxing duck and Partridge Jinyun related to several productive traits in duck. Further analysis on the relation or association between GH gene in Muscovy duck in Indonesia and growth traits.

\section{CONCLUSION}

Body weight gain of male 3-week-old Muscovy ducks was higher than the females, while the highest relative growth of male ducks was obtained at an early period of $0-2$ weeks old, after which the growth rate was relatively steady. GH gene polymorphism, showed different genotypes in black-plumed female ducks.

\section{ACKNOWLEDGMENT}

Sincerest gratitude goes to Directorate
General of Research and Community Service, Ministry of Research Technology and Higher Education and Chairman of Research Centre and Community Service for funding Competence (Hibah Kompetensi) Research Grant.

\section{REFERENCES}

Badyaev AV. 2002. Growing apart: an ontogenetic perspective on the evolution of sexual size dimorphism. Trends in Ecol. Evol. 17(8): 36-378.

Baéza E, J. Williams, D. Guémené and M.J. Duclos. 2001. Sexual dimorphism for growth in Muscovy ducksand changes in insulin-like growth factor I (IGF-I), growth hormone $(\mathrm{GH})$ and triiodothyronine (T3) plasma levels. Reprod. Nutr. Dev. 41(2):173-9.

Baéza, E., G. Marché, and N. Wacrenier. 1999. Effect of sex on muscular development of Muscovy ducks. Reprod. Nutr. Dev. 39: 675682.

Charuta, A., M. Dzierzęcka, M. Pierzchała, R.G. Cooper, E. Poławska and J.O. Horbańczuk. 2013. Sex-related differences of morphometric, densitometric, and geometric parameters of tibia and tarsometatarsal bone in 14-month-old ostriches (Struthio camelus). Poult. Sci. 92:2965-2976.

Ge, X., J. Yu., and H. Jiang. 2012. Growth hormone stimulates protein synthesis in bovine skeletal muscles cells without 
altering insulin-like growth factor-I mRNA expression. J. Anim. Sci. 90:1126-1133.

Ghelghachi A.A., H. Reza Seyedabadi and A. Lak. 2013. Association of growth hormone gene polymorphism with growth and fatness traits in Arian broilers. Int. J. Biosci. 3:216220.

Hai, X.S, B.W. Bin, C.J. Hua, H. Jun, Z. Hongxiao and C.G. Hong. 2007. Polymorphism Analysis on Coding and Regulation Regions of Growth Hormone Gene in Duck. Chinese J. Anim. Vet. Sci. 38(9):907-912.

Hansen, C., N. Yi, Y.M. Zang, S. Xu, J. Gavora and H.H. Cheng, 2005. Identification of QTL For Production Traits in Chickens. Anim. Biotechnol. 16:67-79.

Hull K.L. and S. Harvey. 2001. Growth hormone: roles in female reproduction. J. Endocrinol. 168:1-23.

Kansaku N., A. Nakada, H. Okabayashi, D. Guémené, U. Kuhnlein, D. Zadworny and K. Shimada. 2003. DNA polymorphism in the chicken growth hormone gene: Association with egg production. Anim. Sci. J. 74:243-244.

Knízetová, H., J. Hyánek, B. Kniže, and H. Procházkova. 1991. Analysis of growth curves of fowl. II. Ducks. Brit. Poultry Sci. 32:1039-1053.

Mazurowski A., A. Frieske, D. Kokoszyñski, S. Mroczkowski, Z. Bernacki and A. Wilkanowska. 2015. Examination of growth hormone $(\mathrm{GH})$ gene polymorphism and its association with body weight and selected body dimensions in ducks. Folia Biologica (Kraków). 63:43-50.

Mignon-Grasteau, S., C. Beaumont, J.P. Poivey, and H. de Rochambeau. 1998. Estimation of the genetic parameters of sexual dimorphism of body weight in 'label' chickens and Muscovy ducks. Genet. Sel. Evol. 30:481491.

Murawska, D. 2012. The effect of age on the growth rate of tissues and organs and the percentage content of edible and nonedible carcass components in Pekin ducks. Poult.
Sci. 91:2030-2038.

Murawska, D., K. Kleczek, K. Wawro, and D. Michalik. 2011. Agerelated changes in the percentage content of edible and non-edible components in broiler chickens. Asian-Aust. J. Anim. Sci. 24:532-539.

Narinc, D., E. Karaman, T.Aksoy, and M. Z. Firat. 2014. Genetic parameter estimates of growth curve and reproduction traits in Japanese quail. Poultry Science 93:24-30.

Raji, A.O., J. U. Igwebuike and M. T. Usman. 2009. Zoometrical body measurements and their relation With live weight in matured local muscovy ducks In borno state nigeria. ARPN J. Agr. Biol. Sci. 4(3):58-62.

Sheng-Wai, X., B. Wen-Bin, H. Jun, C. Jun-Hua, S. JIng-Ting and C. Gua-Hong. 2007. Polymorphic analysis of intron 2 and 3 of growth hormone gene in duck. Hereditas, 29:438-442.

Sudoyo, H. 2004. Polimorfisme DNA Mitokondria dan Kedokteran Forensik dalam Mitochondrial Medicine. Lembaga Biologi Molekul Eijkman. Jakarta. P. 43- 55.

Warriss, P.D. 2000. Meat Science : an introductory text. CABI Publishing, Wallingford. UK.

Wu, X., M.J.Yan, S.Y. Lian, X.T. Liu and A. Li. 2014. GH gene polymorphism and expression associated with egg laying in Muscovy ducks (Cairina moschata). Hereditas. 151:14-19.

Wu, Y., A.L. Pan, J.S. Pi, Y.J. Pu, J.P. Du, Z.H. Liang and J. Shen. 2012. One novel SNP of growth hormone gene and its associations with growth and carcass traits in ducks. Mol. Biol. Rep. 39:8027-8033.

Zhang, X.L., X. Jiang, Y.P. Liu, H.R. Du and Q. Zhu. 2007. Identification of AvaI polymorphisms in the third intron of $\mathrm{GH}$ gene and their associations with abdominal fat in chickens. Poult. Sci. 86:1079-1083.

Zhang, Y., Z. Zhu, Q. Xu and G. Chen. 2014. Association of polymorphisms of exon 2 of the growth hormone gene with production performance in Huoyan goose. Int. J. Mol. Sci. 15:670-683. 